\title{
Introduction
}

The Politics of Language from Multiple Perspectives:

Latinidad and Indigenidad

\author{
Serafín M. Coronel-Molina, Indiana University \\ Issue Editor
}

The field of politics of language intersects with language policy and planning, language of politics, language politics, language revitalization, linguistic rights, language laws, and language regimes. ${ }^{1}$ This means that politics of language cannot be completely separated from the above-mentioned fields, since they are interconnected in various ways. In addition, it is fundamental to delve into the notion of politics of language not only from disciplinary and multidisciplinary angles, but also from interdisciplinary and transdisciplinary perspectives.

The politics of language takes place in a mosaic of contexts constituted by real and virtual communities of speakers, and in diverse communicative events and discursive practices. It can be grounded in any number of disciplines and fieldsincluding sociology, political theory, political science, history, linguistics, sociolinguistics, identity politics, gender politics, sociology of language, literature, critical discourse analysis, the semiotics, pragmatics and semantics of political discourses, political economy, linguistic anthropology, philosophy, raciolinguistics, translingualism, folklore, communication and media studies (print and digital), language education, literacy studies - as well as in a wide range of creative works and semiotic resources, such as in iconicity and imagery. Methodologically speaking, the politics of language is studied qualitatively and quantitatively, though the dominant research paradigm is the qualitative approach.

Political speeches and political discourses - with both a capital D and a small d (Gee, 2012) —intersect with discourses that are linguistic, cultural, gender, power, identity, ideological, scientific, or economic in nature. Orality, translinguality, interdiscursivity, transdiscursivity, intertextuality, and transtextuality are considered cornerstones for understanding and defining the politics of language from

1. For further information on the politics of language in the United States, see del Valle (2013); Labov (2010); Mar-Molinero (2000); May (2012); Schmid (2001); Schmidt (2000); Thompson (2016); Zentella (1997 \& 2016). 
micro and macro dimensions, and from multidisciplinary, interdisciplinary, and transdisciplinary perspectives.

\section{Languages in the United States and Latin America}

The United States is a multilingual, pluricultural, and multiethnic country where, without a doubt, English is the dominant and the only de facto official language. To a certain extent, Spanish is another commonly spoken language. According to the United States Census Bureau (2016), the United States' Hispanic population numbers 56.6 million, or $17.6 \%$ of the total population, thus constituting the country's "largest ethnic or racial minority." It is estimated that by 2050 there will be 138 million Spanish speakers in the United States, "making it the biggest Spanish-speaking nation on Earth, with Spanish the mother tongue of almost a third of its citizens." It is obvious, then, that the presence of Spanish in the United States is solid, since persons of Hispanic origin make up the largest minority group. In addition to Spanish, Indigenous languages and their many linguistic hybrid forms are present and robust in the United States and in Latin America:

Recent U.S. Census data place the number of American Indians, Alaska Natives, and Native Hawaiians at approximately 6.4 million, or 2.1 percent of the total population (Hixson, Hepler, \& Kim, 2012; Norris, Vines, \& Hoeffel, 2012). The U.S. Census also reports 169 Native American languages spoken by 370,000 people (Siebens \& Julian, 2011). . . Although smaller in overall numbers, Native Americans reside in every U.S. state and territory, representing more than 560 federally recognized tribes, 619 reservations and Alaska Native villages, and 62 Native Hawaiian homelands. In the USA, the Indigenous language situation is characterized by diverse sociolinguistic ecologies and growing threats to that diversity reflected in twin movements to make English the nation's official language and to circumscribe the teaching of Indigenous and other minoritized languages in school.

Population estimates for Latin America place the number of Indigenous peoples at 40 to 50 million or 10 percent of the population (King, 2008; Lopez \& Sichra, 2008)... The intermingling of Native Americans, enslaved Africans, and Europeans produced other varieties such as Carib PidginArawak in the Caribbean and Garifuna in Central America. Latin America encompasses 20 nation-states, nine dependencies, and a population of 568 million spread out across South, Central, and parts of North America (Garcia et al., 2010, pp. 353-354). With the exception of Uruguay and some Caribbean polities whose original peoples were decimated by colonization, significant numbers of Indigenous peoples reside in every Latin American country (King, 2008; Lopez \& Sichra, 2008). (Coronel-Molina \& McCarty, 2016, pp. 1-11). 
Transnational migration and diaspora movements from around the world are transforming the linguistic diversity and cultural reality of the United States. For instance, as a result of this migration phenomenon, more than 800 languages coexist with English in Queens, New York (Business Insider, 2017). The politics and ideology of multilingualism and multiculturalism are challenging, contesting, and questioning the politics of monolingualism and monoculturalism. Yet, despite the strong presence of Spanish in the United States and Indigenous languages throughout the Americas, asymmetrical power relations vis-à-vis English (in the U.S. context) or Spanish (in the Latin American context) are notorious and vigorous. The politics of language, language policy, and the sociolinguistic reality regarding Indigenous and minoritized languages are asymmetrical in the United States (and Latin America) in large part because these oppressed languages are only recognized locally, but not nationally nor transnationally; and, regrettably, monolingual, populist, and nationalistic ideologies have become the raison d'etre of the vox populi. The linguistic hegemony of English in the United States and Spanish in Latin America (manifested in ideologies, practices, and policies) not only creates or encourages conflicts, confrontations, homogeneity, linguicism, linguistic inequality, and social exclusion, but can also cause linguicide, ethnocide, and cultural erasure. Furthermore, asymmetrical relationships of power, language attitudes, language ideologies, and linguicism-as well as the lack of social, political, linguistic, and cultural capitals-have a negative influence on the preservation of Indigenous and minoritized languages and cultures. These sociopolitical and sociolinguistic phenomena have kept Indigenous and minoritized languages, including Spanish in the United States, in a diglossic —or, in many cases, multiglossic — situation. Very often, historical, social, political, economic, and educational factors force Indigenous and minoritized language speakers to shift from their native language to the dominant one; this necessitates leaving behind their linguistic and cultural practices, as well as their multiplicity of identities, in order to assimilate into the mainstream hegemonic society. Finally, it does not help that linguistic, ethnic, and cultural identities of Indigenous and minoritized communities are not appropriately recognized. For example, Indigenous Latin American peoples are frequently wrongly categorized as Latinas/os or as Hispanics.

There are signs that some of these conditions can be changed, if slowly. The politics of language and its related fields, mentioned above, play a pivotal role in linguistic and cultural maintenance and revitalization. The use of Indigenous and minoritized languages in concrete political discursive practices and the exercise of linguistic and cultural rights are fundamental for the restoration of the functional domains of Indigenous languages, as well as the Spanish language in the United States. In addition, school and society, together with the intergenerational 
transmission of language and culture at home, play a pivotal role in the process of language maintenance and revitalization.

\section{Latinidad, pan-latinidad, LatinX and LatinUs}

Frances Aparicio (2007), in a book chapter entitled "(Re)constructing Latinidad: The Challenge of Latina/o Studies," explores in depth what it means to be Latina/o, and differentiates U.S. Latinas/os from Latin Americans. She examines the various regional, national, and political identities that are often lumped together under the rubric of "Latino"-such as Chicano, Boricua, Tejano, and Central American - and how they intersect with the Latino label. In her study, she does not overlook the importance of socioeconomic, linguistic, racial, generational, and gender factors and how differences among them play into definitions, preconceptions, and permutations of latinidad (the concept) or Latino (the label). The questions she seeks to answer in her chapter are analogous to the ones I raise below in reference to the notion of indigenidad and indianidad.

The concepts of latinidad and pan-latinidad come from the Spanish language and refer to Latin Americans and their descendants in general. Thanks to the pioneering work of Padilla (1985) on Mexicans and Puerto Ricans in Chicago, latinidad is widely used from multi-, inter-, and transdisciplinary perspectives by many scholars in reference to a host of social, cultural, and linguistic practices of Latino/ as in the United States. According to Rodríguez (2003), latinidad is "a particular geopolitical experience but it also contains within it the complexities and contradictions of immigration, (post)(neo)colonialism, race, color, legal status, class, nation, language and the politics of location" (pp. 9-10). ${ }^{2}$ From a sociocultural perspective, latinidad is also constituted by hybridizations and fusions of Latin American cultures, identities, and ethnicities. Latinidad indexes pan-Latino solidarity among Latinas/os in relation to territory, identity, and sense of belonging. It also has important implications for local, regional, national, transnational (global), and hemispheric modalities of belonging. In sum, the definition of latinidad is quite challenging, given the wide repertoire of linguistic, racial, and cultural identities, and the diverse places of origin of individuals (Price, 2007).

Many scholars use latinidad as a marker of cultural practices and identity politics of pan-Latina/o communities. Román and Sandoval (1995) employ the concept to study and assess the "type of organic understanding and appreciation of all things Latino" (p. 558). Rodríguez (2003) delves into it to explain the complex and diverse history of lesbian, gay, bisexual, transgender, and queer (LGBTQ)

2. For further information about latinidad/es and pan-latinidad from diverse perspectives, see Aparicio (2007); Anzaldúa (1987); Bost and Aparicio (2012); Byrd (2015); Flores and Rosaldo (2007); Malavé and Giordani (2015); Miguel (2011); Paredez (2009); Rivera-Servera (2012); Roth (2012); Stavans (1995); and Suárez-Orozco and Páez (2009). 
communities. She also depicts how Latino/as' identities are exhibited, imagined, constructed, performed, and practiced in different domains and social locations.

LatinX is another interesting concept that is becoming popular in recent years, but the inclusion of $\mathrm{X}$ does not sit easily with Spanish orthographic norms, and this is one of the main reasons resistance is emerging from some scholars. For instance, Zentella (in this issue) suggests the use of LatinUs (with a universal U) instead of LatinX to "challenge binary gender assignment in Spanish." She notes "that the $\mathrm{X}$ is difficult to pronounce and violates Spanish orthography." This is a thoughtful contribution to discussions of the matter, but it would be interesting to know whether Zentella's proposal can reach wider acceptance by academic and nonacademic communities.

\section{Indigenidad / Indianidad}

Indigeneity, one of the questions at stake in this volume, is "the state or quality inherent to an Indigenous group — or individual[ - ] that exemplifies their position as an original people who inhabit and were born, or produced naturally, in a given land or region, including their descendants and relations thereof" (Tlakatekatl, 2014). French (2011) appears to concur with this definition: "Just as the imbrications of global and local reveal transnational and translocal connections between international and local identities, it is critical that anthropologists not be dismissive of Indigenous as an identity simply imposed from above, but rather as a process of self-identification" (p. 256). As French notes, such a view serves to valorize the long-term struggles of many "unquestionably Indigenous peoples in the eyes of the world" to decide their own fate-or identity — and to gain political autonomy, while at the same time recognizing the right of relative "newcomers" to indigeneity (so to speak) to self-identify as Indigenous.

Identity (indigeneity) becomes further complicated if we take into consideration the question of identity rooted in native territories. Geertz (1973) suggests the need to challenge the traditional identitarian dichotomy "of autochthony (we are here and have been here forever) [vs.] diaspora (we yearn for a homeland)." He emphasizes just how varied the Indigenous experience really is, calling the displacement and migration of Indigenous peoples an "uneven continuum of attachments." The reasons for such displacements and migrations are as varied as the people, ranging from moving from rural to urban areas for economic reasons to being forcefully expelled from their traditional lands. In all cases, however, they are "improvising new ways to be native" (p. 215). ${ }^{3}$

3. For further discussions on indigeneity, see Brown and Sant (1999); Forte (2013); Pratt (2007); Taylor (2009). 
The massive waves of Indigenous transnational migration from Latin America to the United States in recent years bear out Geertz's perspicacity from more than 40 years ago. This diaspora has further changed, complicated, challenged, and contested the construction and reconstruction of race, ethnicity, language, culture, and identity. The notions of latinidad and even pan-latinidad are not sufficient to encompass the concept of indigenidad or indianidad. In other words, latinidad/es and pan-latinidad do not cover the multilingual, pluriethnic, multicultural, and translingual make up of indígenas, indígenas mestizas/os, afro indígenas, and people with other hybrid ethnicities and identities living in the United States. Spanish is the lingua franca in Latin America and Spain, just as Portuguese is in Brazil. However, not everybody speaks Spanish in Latin America, nor comes from a Latin heritage. According to Yescas (2010), the earliest Indigenous people documented as legal migrants to the United States were P'urepechas from Michoacan, Mexico in the 1960s. This was during the Bracero Program, which allowed Mexicans to enter the United States as legal temporary agricultural workers. Other Indigenous groups followed during the Bracero program, including Hñañus, Mixtecs, and Zapotecs; many of these groups have either stayed or continue to migrate without documents. Later, in the 1980s, Mayans from the Yucatan Peninsula made their way up into California, where, rather than working in agriculture, they found jobs in construction and service industries.

The New York Times (2014) reported on a 2013 survey carried out by the Mexican Consulate in New York to find out more about the Indigenous Mexican population living within their jurisdiction. They found that there were 16 different Indigenous Mexican languages spoken, with Nahuatl and Mixtec being the most common. The U.S. Census Bureau's most recent data indicate there are more than 8,700 Central American immigrants over the age of four who speak their Indigenous language, but speak little or no English. Those data, however, do not offer insights into the Spanish-language proficiency of these immigrants; this is a significant oversight and one more reflection of the linguistic ideologies of the hegemonic, monolingual centers of power in the United States. Spanish could potentially serve as a viable means of communication for them, but it is invalid to assume that because they are from Latin America they speak Spanish. Hence, those who speak neither English nor Spanish are doubly handicapped, in terms of communication.

In the greater New York metropolitan area, Spanish is a lingua franca among the large Latin American immigrant community. In fact, many Indigenous immigrants will learn Spanish before they learn English—-that is, if they ever do learn English. One charity organization, Little Sisters of the Assumption Family Health Service, offers English as a Second Language (ESL) classes. About 10 years ago, the staff of that organization, on discovering that many Indigenous immigrants spoke no more Spanish than they did English and could read in neither language, decided 
it would be easier for these new immigrants to learn Spanish rather than English, since they lived in environments in which Spanish was the primary language. So the organization's ESL classes became SSL classes, which helped the Indigenous immigrants on one level, but hobbled them on another.

Other challenges to prevailing paradigms and definitions of Latino/a studies, Latin American studies, and Native American studies come from the first generation of youth born in the United States to Indigenous or Afro-Indigenous parents, and from individuals who do not meet the heteronormative expectations of Western paradigms. Where do those youth and individuals fit within discussions of latinidad and pan-latinidad? Are U.S.-born children of Indigenous or Afro-Indigenous parents still Indigenous or Afro-Indigenous? Typically, only Western paradigms and worldviews are taken into account in these discussions. So, should indígenas and afro-indígenas be categorized as U.S. Latino/as under the umbrella of latinidad, pan-latinidad, latinX and hispanidad? How about the lesbian, gay, bisexual, transgender and queer (LGBTQ) indígenas? I would argue that Quechua, Aymara, Maya, Zapoteco, Nahuatl, Ashaninka, Shipibo, Mapuche, Yanomani, Xavante indígenas, etc. and afro-indígenas are not Latino/as and should not be labeled as such, or as hispanas/os. In this sense, latinidad, pan-latinidad/es, and LatinX are different constructs than indigenidad/indianidad, and they should not be assumed to be the same. In any case, the notion of pan-indigenidad/es or pan-indianidad/es could be the mantle that holistically embraces all categories of Indigenous Peoples, taking into consideration their distinct or multiple identities, backgrounds, places of origin, and (local or global) life trajectories.

On the other hand, it seems to me that criolla/o, afro-latina/o, mestiza/o or mistis, ${ }^{4}$ which are hybridized forms of ethnicities and identities, may be categorized as latinas/os or hispanas/os. However, because of the process of re-Indianization, some mestizo/as and indígenas mestizo/as (de la Cadena, 2000) would prefer to call themselves indigenas by making reference to their local territories and by claiming their ancestral roots. In other cases, because of the process of de-Indianization,

4. Criollo/a, in its most general sense in Latin American culture, is simply a person of European ancestry who was born in Latin America. However, over time it has come to have something of a sociopolitical connotation, referring primarily to light-skinned people speaking Spanish as their first (or often only) language; it is the sector of society which wields the greatest political power. Mestizo/a, on the other hand, is a term that usually refers to the mixing of races, generally Indians and whites. However, this word has also come to have sociopolitical connotations: "mestizaje separates rather than unites the population: the misti, or highland mestizo ... mediate[s] between the city and the Indian communities by accepting privileges from the whites in order to dominate the Indians" (Mallon, 1996, p. 293). According to de la Cadena (2000), neither Indian nor mestizo[a] have straightforward meanings any more. She argues that the word Indian now means an Indigenous person who is poor and uneducated, illiterate, and lives in rural areas. Mestizos, in contrast, are urban, usually literate, and have achieved some degree of economic success, while still claiming Indigenous heritage and maintaining Indigenous cultural practices. 
some indígenas would choose to identify themselves as latinas/os or hispanas/os. Unfortunately, the U.S. Census Bureau is unable to make such fine distinctions, so all immigrants coming from Latin America are considered "Latino or Hispanic," regardless of their multifaceted identity constructs and their multiplicity of languages, cultures, and ethnicities. But should land, place, context, and territory be strong markers of identity for all immigrants from Latin America in the United States? Or are we trying to homogenize, under the Latina/o rubric, the multiple layers of identity and ethnicities claimed by diverse populations from the vast Latin American territory? These are fundamental questions that need to be properly addressed and reframed in order to avoid imposition of hegemonic or standardized identity labels, for instance, to Indigenous Peoples who do not identify themselseves as "Latinas/os".

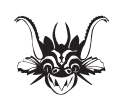

\section{In This Issue}

This "Politics of Language" issue of Chiricú Journal: Latina/o Literatures, Arts, and Cultures explores language as an instrument of power, identity, and politics from multidisciplinary, interdisciplinary, and transdisciplinary perspectives. It traces the linguistic diversity of Latina/o and Indigenous communities in the United States and in transnational contexts involving the United States. The contributions to this volume are in Spanish, English, Portuguese, and in hybrid languages, though (it must be said) despite our outreach efforts there remains a notable absence of content in Indigenous languages. Creative works include short stories, poems, interviews, personal essays, and visual art. Critical works concentrate on facets of language in political, historical, ideological, pedagogical, literary, artistic, and cultural contexts.

In our lead article, "Limpia, fija y da esplendor': Challenging the Symbolic Violence of the Royal Spanish Academy," Ana Celia Zentella describes the functions of the Royal Spanish Academy (RAE), whose motto and mission, since 1713, has been to "clean, fix, and give splendor" to the Spanish language. Zentella argues that the RAE has leveraged its mission in order to "perpetuat[e] ... negative stereotypes" of any variety of Spanish that does not follow the norms prescribed by the Academy. This amounts, she asserts, to "symbolic violence" directed at anyone speaking nonstandard varieties of Spanish and "damaging repercussions including language loss, linguistic profiling and violent hate crimes." As something of a case study, she examines the RAE's position with regard to Spanglish, showing how what the organization says (or does not say) influences Spanglish speakers' perspectives 
and attitudes. Zentella offers an anthropolitical linguistic analysis of the situation that demonstrates "how the racialization of LatinUs, which views Anglos/Whites and English as superior, is at the root of purist postures." Such positions must be denounced, Zentella argues, "the Spanglish label itself must be defended."

In the article, "Quechua Language Programs in the United States: Cultural Hubs for Indigenous Cultures," Américo Mendoza-Mori begins with a brief overview of the status of Quechua in its native environment and around the world. Interestingly, although the language has a base of nearly eight million native speakers, making it "the most widely spoken American Indigenous language," it is still considered an endangered language because of its tenuous sociopolitical status and the rapid decline in speakers in the countries where it has traditionally been spoken (Bolivia, Peru, Ecuador, and parts of Argentina and Colombia). The rest of the article is dedicated to describing the author's experience learning and teaching Quechua at different universities in the United States, as well as other academic efforts in the United States to promote the language. He discusses different initiatives being undertaken at various levels, both within academia and among the wider community, and the importance of Indigenous language-planning and revitalization efforts within academia. Mendoza-Mori maintains that those efforts can advance a more diverse education system, which he views as essential to improving the status of Quechua and preventing — or even reversing_language loss.

Sergio Loza's contribution, "Transgressing Standard Language Ideologies in the SHL Classroom," examines language ideologies and how they are transmitted within the Spanish Heritage Language (SHL) classroom —an important topic that is sadly lacking in empirical research. To remedy that deficit, Loza conducted a study in the classrooms of six SHL instructors from a four-year college in the Southwest, collecting his data through questionnaires, interviews, and a written correction task. Upon analysis, he identified several important trends: instructors variously embraced antihegemonic ideologies that challenged notions of standard Spanish, accepted SHL-learners' nonstandard varieties and linguistic choices, and/or encouraged students to broaden their linguistic repertoires in both standard and nonstandard varieties. At the same time, some instructors unwittingly propagated standard language ideologies by way of their classroom explanations or corrective feedback, which sometimes did not clearly distinguish between standard and nonstandard varieties. The results would seem to indicate that "teacher training must include a critical awareness of standard language ideologies and their implications in SHL pedagogy and assessment."

Language ideologies sometimes reveal themselves in daily language practices, such as in labeling. In the scholarly exchange, "What is an ' $\mathrm{X}$ ': An Exchange about the Politics of Latinx," Kathleen M. de Onís moderates a discussion among five scholars about the meaning, utility, and implications of the term "Latinx." A presumably gender-neutral term that has grown in popular usage, Latinx sheds light 
on intersections between gender, sexuality, language, power, and identity. It is through the disagreements and tensions among participants that broader discussions and points of contention can be identified. Ultimately, the intention of the article is to further ongoing dialogue about "the politics, intersectional social locations, and exigencies implicated in discussions about 'Latinx' and similar linguistic choices."

The politics of language are, of course, infused throughout Latina/o literature. In the article, "Los diablos y peregrinos del lenguaje: la técnica de defamiliarización en dos obras chicanas," Jennifer Servi-Roberts explains how Chicano literature seeks to defamiliarize history and identity in the novels Peregrinos de Aztlán, by Miguel Méndez, and El diablo en Texas, by Aristeo Brito. Employing Shklovsky's theory of defamiliarization and Bakhtin's ideas about heteroglossia, polyglossia, and language as cosmovision, Servi-Roberts analyzes ways the authors use different languages and specific vocabularies to challenge preconceived concepts of history and identity, and thereby change the reader's perspective. In the article, "Language of the Flesh: Colonial Violence and Subversion in the Poetry of Judith Ortiz Cofer," Roberta Hurtado takes as a starting point the forced sterilization of one-third of Puerto Rican women starting in the 1960s. La operación, as it was known on the island, was the result of U.S. colonial policy and ongoing colonial narratives. In a search for decolonial counternarratives, Hurtado argues for the "creation of a 'language of the flesh' within poetry" that could serve to sabotage such colonial narratives and communicate the corporeal experiences of Puerto Rican women as they confront and resist coloniality.

"The politics of language" that lie at the heart of this issue of Chiricú Journal span the scholarly articles as well as the creative works and book reviews that follow. Collectively, these interventions demonstrate the diverse ways that language encodes ways we interpret our world, our relationships, and our lived experience.

\section{References}

Anzaldúa, G. (1987). Borderland/La frontera: The new mestiza. San Francisco: Aunt Lute Books.

Aparicio, F. R. (2007). (Re)constructing latinidad: The challenge of Latina/o studies. In J. Flores \& R. Rosaldo (Eds.), A companion in Latina/o studies. Oxford, UK: Wiley-Blackwell.

Bost, Z., \& Aparicio, F. R. (Eds.). (2012). The Routledge companion to Latino/a literature. London, UK: Routledge.

Brown, J., \& Sant, P. M. (1999). Indigeneity: Construction and re/presentation. New York, NY: Nova Science Publisher.

Byrd, S. K. (2015). The sounds of Latinidad: Immigrants making music and creating culture in a southern city. New York, NY: New York University Press.

Coronel-Molina, S. M., \& McCarty, T. L. (2016). Introduction. In S. M. Coronel-Molina \& T. L. McCarty (Eds.), Indigenous language revitalization in the Americas (pp. 1-11). New York, NY: Routledge. 
De la Cadena, M. (2000). Indigenous mestizos: The politics of race and culture in Cuzco, Peru, 19191991. Durham, NC: Duke University Press.

Del Valle, J. (Ed.). (2013). A political history of Spanish: The making of a language. Cambridge, UK: Cambridge University Press.

Flores, J., \& and Rosaldo, R. (Eds.). (2007). A companion for Latina/o studies. Malden, MA: Wiley-Blackwell.

French, J. H. (2011). The power of definition: Brazil's contribution to universal concepts of indigeneity. Indiana Journal of Global Legal Studies, 18(1). Retrieved from http://www.repository.law .indiana.edu/ijgls/vol18/iss1/11.

Forte, M. C. (Ed.). (2013). Who is an Indian? Race, place, and the politics of indigeneity in the Americas. Toronto: University of Toronto Press.

Gee, J. P. (2012). Social linguistics and literacies (4th Ed.). NY: Routledge.

Geertz, C. (1973). The interpretation of cultures. New York, NY: Basic Books.

Labov, W. (2010). Dialect diversity in America: The politics of language change. Charlottesville, VA: University of Virginia Press.

Lubin, Gus. (2017, Feb. 15). Queens has more languages than anywhere in the world-here's where they're found. [News article] Retrieved from http://www.businessinsider.com /queens-languages-map-2017-2.

Malavé I., \& Giordani, E. (2015). Latino stats: American Hispanics by the numbers. New York, NY: The New Press.

Mar-Molinero, C. (2000). The politics of language in the Spanish-speaking world: From colonization to globalisation. New York, NY: Routledge.

May, S. (2012). Language and minority rights: Ethnicity, nationalism and the politics of language (2nd ed.). NY: Routledge.

Miguel, G. S. (2011). Embracing Latinidad: Beyond Nationalism in the History of Education. Journal of Latinos \& Education 10.1, pp. 3-22.

Padilla, F. M. (1985). Latino ethnic consciousness: The case of Mexican Americans and Puerto Ricans in Chicago. Notre Dame, IN: University of Notre Dame Press.

Paredez, D. (2009). Selenidad: Selena, Latinos, and the performance of memory. Durham, NC: Duke University Press.

Pratt, M. L. (2007). Afterword. Indigeneity today. In M. de la Cadena \& O. Starn (Eds.), Indigenous experience today (pp. 397-404). Oxford, UK: Berg.

Price, P. L. (2007). Cohering culture on calle Ocho: The pause and flow of latinidad. Globalizations, 4(1,) pp. 81-99.

Rivera-Servera, R. H. (2012). Performing queer latinidad: Dance, sexuality, politics. Ann Arbor, MI: University of Michigan Press.

Rodríguez, J. M. (2003). Queer latinidad: Identity practices, discursive spaces. New York, NY: New York University Press.

Román, D., \& Sandoval, A. (1995). Caught in the web: Latinidad, AIDS, and allegory in Kiss of the Spider Woman, the musical. American Literature, 67(3), pp. 553-585.

Roth, W. (2012). Race migrations: Latinos and the cultural transformation of race. Stanford, CA: Stanford University Press.

Schmid, C. L. (2001). The politics of language: Conflict, identity, and cultural pluralism in comparative perspective. Oxford, UK: Oxford University Press.

Schmidt, R. (2000). Language policy and identity in the United States. Philadelphia, PA: Temple University Press. 
Stavans, I. (1995). The Hispanic condition: Reflections on culture and identity in America. New York, NY: HarperCollins, 1995.

Suárez-Orozco, M. M., \& Páez, M. M. (Eds.). (2009). Latinos: Remaking America. Berkeley, CA: University of California Press.

Taylor, A. (2009). Indigeneity in the Mexican cultural imagination: Thresholds of belonging. Tucson, AZ: The University of Arizona Press.

Tlakatekatl. (2013, Oct. 16). The problem with indigeneity. [Web log comment]. Retrieved from https://mexika.org/2014/09/17/\%C2\%ADthe-problem-with-indigeneity.

Semple, Kirk. (2014, Jul. 10). Immigrants who speak indigenous languages encounter isolation. The New York Times. Retrieved from https://www.nytimes.com/2014/07/11/nyregion/immigrants -who-speak-indigenous-mexican-languages-encounter-isolation.html?_r=0.

Thomson, M. (2016). Enough said: What's gone wrong with the language of politics? New York, NY: Saint Martin's Press.

United States Census Bureau. (2016, Oct. 12). “FFF: Hispanic Heritage Month 2016.” Retrieved from https://www.census.gov/newsroom/facts-for-features/2016/cb16-ff16.html

Yescas, Carlos. (2010, Mar. 31). Hidden in plain sight: Indigenous migrants, their movements, and their challenges. [Article] Retrieved from http://www.migrationpolicy.org/article /hidden-plain-sight-indigenous-migrants-their-movements-and-their-challenges.

Zentella, A. C. (1997). Growing up Bilingual: Puerto Rican Children in New York. Malden, MA: Wiley-Blackwell.

Zentella, A. C. (2016). Spanglish: Language politics vs. el habla del pueblo. In R. E. Guzzardo Tamargo, C. M. Mazak, \& M. C. Parafita Couto (Eds.), Spanish-English codeswitching in the Caribbean and the US. Amsterdam: John Benjamins.

Serafín M. Coronel-Molina is Associate Professor in the Department of Literacy, Culture, and Language Education at Indiana University. He is the author of Language Ideology, Policy and Planning in Peru (Multilingual Matters, 2015), and co-editor of Indigenous Language Revitalization in the Americas (2016). 